\title{
Induction of Pathogenesis-Related (PR) Proteins as A plant Defense Mechanism for Controlling the Cotton Whitefly Bemisia tabaci
}

\author{
Soliman, A., M., Idriss, M. H., El-Meniawi, F. A. and Rawash, I. A. \\ Department of Applied Entomology and Zoology, Faculty of Agriculture, \\ Alexandria University, Alexandria, Egypt.
}

\begin{abstract}
The activities of four pathogenesis-related (PR) proteins (Beta-1, 3-glucanase, chitinase, polyphenol oxidase and peroxidase) were determined in both Bemisia tabaci infested and non-infested tomato plants. Beta-1, 3-glucanase activity in non-infested and 24, 48, 72 and $96 \mathrm{~h}$ infested tomato plants with $B$. tabaci, were spectrophotometrically determined. The results show that the activity of the enzyme was significantly increased in comparison to control. The activity of $\beta$ 1,3-glucanases was slightly pronounced one day after infestation and reached maximum level after three days (3.3-folds than control). The accumulation of chitinase started to increase with time one day after infestation (1.2 folds over control). Chitinase specific activity increased significantly after $48 \mathrm{~h}$ of whitefly feeding and continued in elevation with time until it reached the maximum in the fourth day of feeding. In all treatments, polyphenol oxidase activity after $24,48,72$ or $96 \mathrm{~h}$ of whitefly infestation increased more than control. The activity increased substantially after $24 \mathrm{~h}$ of feeding of whitefly ( 4.3 folds than control). The maximum rate of activity of peroxidase was exhibited after $48 \mathrm{~h}$ exposure to whitefly that it had recorded 1.8 folds greater than 0 -time and followed by $24 \mathrm{~h}$ whitefly-infested plants with 1.6 -folds increase in peroxidase activity compared to control then $72 \mathrm{~h}$ and $96 \mathrm{~h}$ after infestation (1.35 and 1.27 folds greater than control respectively). The PR proteins play an important defensive role against whiteflies. Pseudomonas chlororaphis (nonpathogenic bacteria) reduced the mean numbers of whitefly adults $/ \mathrm{cm}^{2}$ by about $36.5 \%$. These results provide clear evidence that tomato plants resistance is based on a variety of defense systems against several pests. The treatment of tomato plants with Pseudomonas spp. caused rapid trigger systemic defenses against herbivores and pathogens.
\end{abstract}

Keywords:Bemisia tabaci, Pathogenesis-Related(PR) Proteins, Defense, Pseudomonas spp.

\section{INTRODUCTION}

Many investigations revealed that one of the plant defense tools, that help in protecting them from pathogens or insects attack is lifting concentrations of secondary compounds or assortment of host proteins, many of which are termed PR proteins (Carr and Klessig, 1989; Bol et al., 1990; Linthorst, 1991). Plants react to different natural environmental challenges with diverse biochemical changes. For case, they commonly hoist concentrations of secondary compounds in reaction to pathogen infection or insect herbivory (Karban and Baldwin, 1997). Other plant reactions incorporate lignification production of PR proteins (Vance et al., 1980; Diaz and Merino, 1998). The first PR-protein was discovered in 1970. Since 1970s, a number of PR proteins have been recognized in various plant species (Liu and Xue, 2006). PR proteins are thought to play a part in plant defense (Van Loon, 1999). The term PR proteins was coined in 1980 for proteins produced by the host plant, but induced only by pathogens, pests, or other stress-related circumstances (Antoniw and White, 1980). So, any host protein actuated by any type of infectious agent or comparable condition would be known as PR protein. The PR proteins are known to be communicated in reaction to various external stimuli, counting pathogens, injuring, chemical elicitors and hormones (Brederode et al., 1991; Inbar et al., 1998). PR proteins are belonged to many families exemplifing $\beta$-1,3-glucanases, chitinases, thaumatin, proteinases, peroxidases, ribonuclease-like proteins, or proteins of unknown function (Van Loon, 1999), and it differs in its accumulation among depending on the kind of stimulant and the host plant diversity. In spite of a ceaselessly developing information about the structure of PR proteins and how they work, their contribution in plant defense is not completely caught on. In tomato plants, whiteflies alone have been shown to induce the production of specific PR proteins $(\beta$-1,3-glucanase, chitinase, $\mathrm{P} 2$, and $\mathrm{P} 4)$ to accumulate (Mayer et al., 1996). In tomato plants, it is inconspicuous how the level of PR protein aggregation as a reaction of whitefly feeding compares to accumulation when whiteflies acquired a plant virus.

On the other hand, some plant growth promoting microorganisms could promote protective activity and encourage plant resistance against soil borne pathogens (Whipps, 2001). useful micro-organisms that promote plant validity, through the raise of plant resistance against biotic stresses include bacteria, such as Pseudomonas spp. Also, direct connection with plant pathogens, bio agents announced to induce systemic resistance 
in plants (Srivastava et al., 2010). Ramamoorthy et al. (2002) reviewed that Pseudomonas fluorescens was found to protect tomato plants from wilt disease. Activities of peroxidase and polyphenol oxidase spread in bacterized tomato root tissues exposed to the pathogen at one day after pathogen challenge and obtain the peak at the $4^{\text {th }}$ day. So also, $\beta-1,3$ glucanase and chitinase were produced at higher levels at 3-5 days of inoculation in bacterized plants. During the present study, we aimed to develop a plan of an IPM program for $B$. tabaci under greenhouse conditions.

\section{MATERIALS AND METHODS}

\section{1- Laboratory culture of the cotton whitefly} Bemisia tabaci:

The cotton whitefly Bemisia tabaci (Gennadius) (Order: Hemiptera, Aleyrodidae) was reared on healthy tomato plants. The mother colony was established by late Prof. Mourad El-Helaly and has been reared under greenhouse conditions at Department of Applied Entomology since 1960s. In 2000 , the mother colony of whiteflies was reidentified by Dr. Jon Martin, Insect/Plant Division, Department of Entomology, The Natural History Museum, UK.

\section{2- Induction of PR proteins in tomato plants.}

2.1- Experimental design:

Tomato seeds were sown in trays, then transferred singly to pots. When the seedlings had 7 leaves, 15 tomato plants were arranged in a completely randomized design in five groups. Each three plants represent a treatment. The first group (control plants) was kept in an insect-proof green house at $30 \pm 5^{\circ} \mathrm{C}, 65 \pm 5 \mathrm{RH}$ and under natural light conditions. Tomato plants of the other four groups were covered by glass lantern and each plant was exposed to whitefly at the rate of 50 adults for 24 , 48, 72 and 96 hours.

\section{2- Total protein determination:}

Total protein content was determined by the method of Bradford (1976), using bovine serum albumin (BSA) as standard. Fifty mg of commasie blue G-250 were dissolved in $25 \mathrm{ml}$ ethanol $95 \%$ then added to $50 \mathrm{ml} \mathrm{O}$-phosphoric acid $85 \%$. The mixture was diluted to $500 \mathrm{ml}$ with $\mathrm{H}_{2} \mathrm{O}$ and filtered through filter paper (whatman no.1). One tenth (0.1) $\mathrm{ml}$ of plant extract samples were added to $5 \mathrm{ml}$ of reaction media. The tubes were well shaken using a vortex and were allowed to stand for $10 \mathrm{~min}$. at room temperature after which the developed color was measured at $595 \mathrm{~nm}$.

\section{3- Enzyme Extraction:}

One gram of leaf samples was collected from both $B$. tabaci infested and non-infested plants, and crushed with pre-cooled mortar and pestle in $5 \mathrm{ml}$ of $0.05 \mathrm{M}$ sodium acetate buffer $(\mathrm{pH} 5.0)$ in the presence of 0.3 gm polyvinyl pyrrolidone (PVP) and centrifuged at $16000 \mathrm{~g}$ for $15 \mathrm{~min}$ at $4^{\circ} \mathrm{C}$. The supernatant was used in enzyme assay as crude enzyme extract.

\section{4- Assay of $\boldsymbol{\beta}$-1,3-glucanase activity:}

Beta-1,3-glucanase activity was colorimetrically assayed by the laminaria dinitrosalicyclate method (Saikia et al., 2005). The reaction mixture consisted of $62.5 \mu \mathrm{L}$ of $0.04 \%$ Laminarin and $62.5 \mu \mathrm{L}$ of enzyme extract. The reaction was carried out at $40^{\circ} \mathrm{C}$ for $10 \mathrm{~min}$. The reaction was stopped by adding $375 \mu \mathrm{L}$ of dinitrosalicylic acid and heated for $5 \mathrm{~min}$. on boiling water, Eppendorf were shaken using a vortex and its absorbance was measured at $500 \mathrm{~nm}$. The enzyme activity was expressed as $\mathrm{Ug}_{-}{ }^{1}$ fresh weight (quantity of enzyme that liberates one $\mu \mathrm{M}$ glucose per a minute under experimental conditions).

\section{5- Assay of chitinase activity:}

To determine the chitinase activity in both $B$. tabaci infested and non-infested plants, one $\mathrm{ml}$ of the enzyme extract was added to one $\mathrm{ml}$ of $1 \%$ colloidal chitine in $0.05 \mathrm{M}$ citrate phosphate buffer (pH 6.6) and mixed by shaking in test tube then kept in water shaking bath at $37^{\circ} \mathrm{C}$ for $75 \mathrm{~min}$. The reaction was then stopped by adding one $\mathrm{ml}$ of dinitrosalicylic acid (Monreal and Reese, 1969) and heated for $5 \mathrm{~min}$., then cooled and centrifuged at $3000 \mathrm{rpm}$ for $5 \mathrm{~min}$. to get rid of chitin before measuring O.D. at $540 \mathrm{~nm}$. Chitinase activity was defined as $\mathrm{Ug}^{-1}$ fresh weight $(\mu \mathrm{M} \quad \mathrm{N}$ Acetylglucosamine liberated per a minute).

2.6- Assay of ployphenol oxidase activity:

Ployphenol oxidase activity was determined according to Mayer et al. (1965). Two hundred $\mu \mathrm{L}$ of the enzyme extract was added to $1.5 \mathrm{ml}$ of $0.1 \mathrm{M}$ Phosphate buffer ( $\mathrm{pH} 7)$. To start the reaction 200 $\mu \mathrm{L}$ of $0.01 \mathrm{M}$ catechole in phosohate buffer $(\mathrm{pH} 7)$ was added and the activity was expressed as change in absorbance at $495 \mathrm{~nm} / \mathrm{min}$.

\section{7- Assay of peroxidase activity:}

The reaction mixture consisted of $0.5 \mathrm{ml}$ of enzyme extract and $0.5 \mathrm{ml}$ of $1 \% \mathrm{H}_{2} \mathrm{O}_{2} .1 .5 \mathrm{ml}$ of $0.05 \mathrm{ml}$ pyrogallol was added to every sample separately and incubated at room temperature. The enzyme activity was expressed as the change in absorbance at $420 \mathrm{~nm}$ at $1 \mathrm{~min}$. intervals (Hammerschmidt et al., 1982).

\section{8- Statistical analysis:}

Statistical analysis of the obtained data and all the probable comparison combination were analyzed in a Randomized Complete Blocked Design (RCBD) by using SAS (1997) at probability level of 0.05 .

3- Using of non-pathogenic bacteria
(Pseudomonas spp.) to induce proteins in tomato plants:

3.1- Preparation of bacterial culture:

Isolates of $P$. fluorescens and P. chlororaphis were kindly provided by Dr. Nader Abd Elwahab, Associate Professor of Plant Pathology, Department 
of Plant Pathology, Faculty of Agriculture, Alexandria University. Isolates were grown in King's B agar plates for $48 \mathrm{~h}$ at $28^{\circ} \mathrm{C}$. The bacterial isolates were multiplied in King's B broth for $48 \mathrm{~h}$ at $28^{\circ} \mathrm{C}$ in $500 \mathrm{ml}$ flasks suspended for two days and turbidity was adjusted calorimetrically to approximately $10^{9}$ Colony Forming Unit CFU/ml. Fifty $\mathrm{ml}$ of bacterial suspension were applied to each pot.

\section{2- Experimental design:}

To assess the ability of soil born rhizosphere bacteria to induce PR proteins in tomato plants and the possibility of utilization this phenomenon as defense mechanism against whitefly, tomato plants bearing each 7 leaves were divided into four groups. The first group was healthy tomato plants reared in a whitefly-free greenhouse. The second group was tomato plants which were artificially wounded daily for a week and reared in a whitefly-free greenhouse. The third group was tomato plants infested with $B$. tabaci adults for a week. The fourth group was tomato plants that were infected with $P$. chlororaphis or $P$. fluorescens and reared in a whitefly-free greenhouse. Each treatment was replicated five times. Tomato plants of all treatments were aligned in a completely randomized design in greenhouse at $30 \pm 5 \mathrm{C}^{\circ}, 65 \pm 5 \mathrm{RH}$ under natural light conditions. Whitefly adults were collected from mother colony and released at the center of the greenhouse. Numbers of adult $/ \mathrm{cm}^{2}$ on each plant were daily recorded. The experiment was repeated for four successive days.

\section{3- Statistical analysis:}

Obtained data were analyzed in factorial (two factors) design using ANOVA (SAS, 1997) and the mean numbers of $B$. tabaci adults $/ \mathrm{cm}^{2}$ were compared by using the least significant difference test (LSD) at probability level of 0.05 .

\section{RESULTS}

1- The effect of $B$. tabaci infestation on $\beta$-1, 3glucanase activity in tomato plants:
Beta-1,3-glucanase activities, specific activity and protein content for infested and non-infested leaf samples are illustrated in Table 1 and Figures 1 , $2,3 \& 4$. In all treatments, activities of $\beta-1,3-$ glucanase significantly increased than control. Increase in $\beta$-1,3-glucanase activity was exhibited in plants after one day of infestation.

The activity of $\beta$-1,3-glucanase reached maximum level after three days (3.3 folds over control) and that was also observed 24 and $48 \mathrm{~h}$. after infestation that the activity was 1.4 and 2 folds respectively (Figures, 1\&4), then withdraw in the fourth day though it remained more active than control.

As shown in Table 1 and Figures 2 \& 4, exposure of tomato plants to feeding by whitefly caused an increment in the leaf protein content in infested plants with time when compared to noninfested plants. The total protein content increased from $0.61 \mathrm{mg} \mathrm{g}^{-1}$ fresh weight in control plants to $0.91 \mathrm{mg} \mathrm{g}^{-1}$ fresh weight in $96 \mathrm{~h}$. infested plants. Although there was increment in leaf protein content with time; there was no significant differences among days1, 2, and 3 after infestation or between days 3 and 4 . The increment in leaf protein content in infested plants suggested that there might by stimulation of some plant proteins occurring simultaneously, with the apparent induction of PR proteins.

Like the enzyme activity, specific activity of $\beta$ 1,3-glucanase followed the same pattern (Table, 1 and Figures, $3 \& 4$ ); it reached maximum level after three days of infestation and it was significantly higher than any treatment, then it has retracted in the fourth day and kept more significantly higher than control. There were no significant differences in specific activity between plants that exposed to whitefly for 48 or $96 \mathrm{~h}$. Also, no significant difference was observed between $24 \mathrm{~h}$. whiteflyexposed plants and 0 -time (control).

Table 1: Time-course activity of $\beta$-1,3-glucanase and protein content in the infested tomato plants with the cotton whitefly $B$. tabaci.

\begin{tabular}{lccccc}
\hline \multirow{2}{*}{ Parameters } & \multicolumn{5}{c}{ Time in hours } \\
\cline { 2 - 6 } & $\mathbf{0 - t i m e}$ & $\mathbf{2 4}$ & $\mathbf{4 8}$ & $\mathbf{7 2}$ & $\mathbf{9 6}$ \\
\hline \multirow{2}{*}{ Glucanase activity* } & $15.96 \pm 1.04$ & $23.05 \pm 0.41$ & $31.96 \pm 0.38$ & $53.37 \pm 0.30$ & $37.69 \pm 0.66$ \\
& $\mathrm{E}$ & $\mathrm{D}$ & $\mathrm{C}$ & $\mathrm{A}$ & $\mathrm{B}$ \\
\hline \multirow{2}{*}{ Protein content** } & $0.6143 \pm 0.02$ & $0.7375 \pm 0.01$ & $0.7964 \pm 0.01$ & $0.8393 \pm 0.02$ & $0.9161 \pm 0.06$ \\
& $\mathrm{C}$ & $\mathrm{B}$ & $\mathrm{B}$ & $\mathrm{AB}$ & $\mathrm{A}$ \\
\hline \multirow{2}{*}{ Specific activity*** } & $25.98 \pm 1.32$ & $31.29 \pm 1.15$ & $40.15 \pm 0.88$ & $63.63 \pm 1.12$ & $41.51 \pm 3.03$ \\
& $\mathrm{C}$ & $\mathrm{C}$ & $\mathrm{B}$ & $\mathrm{A}$ & $\mathrm{B}$ \\
\hline
\end{tabular}

Values are means \pm S.E of 3 replicas.

Means followed by the same letter(s) within the same row are not significantly different at 0.05 probability level.

* The enzyme activity was expressed as $\mathrm{Ug}_{-}{ }^{1}$ fresh weight (quantity of enzyme that liberates one $\mu \mathrm{M}$ glucose per a minute under experimental conditions).

** The protein content was expressed as $\mathrm{mg} \mathrm{g}^{-1}$ fresh weight.

*** Specific activity $=$ enzyme activity $\div$ protein content. 


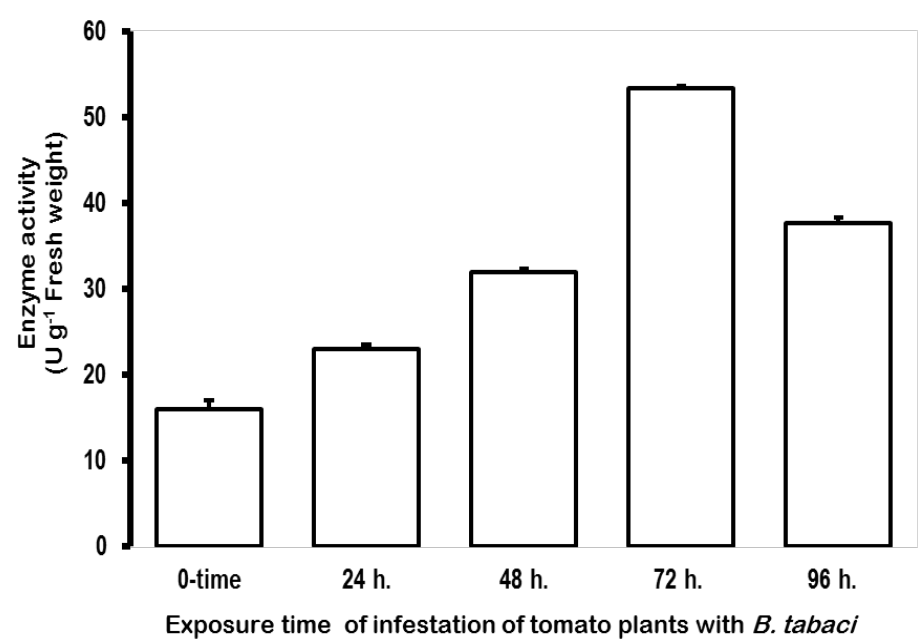

Figure 1: The effect of time-course on the enzyme activity of $\beta$-1,3-glucanase in the infested tomato plants with the cotton whitefly B. tabaci.

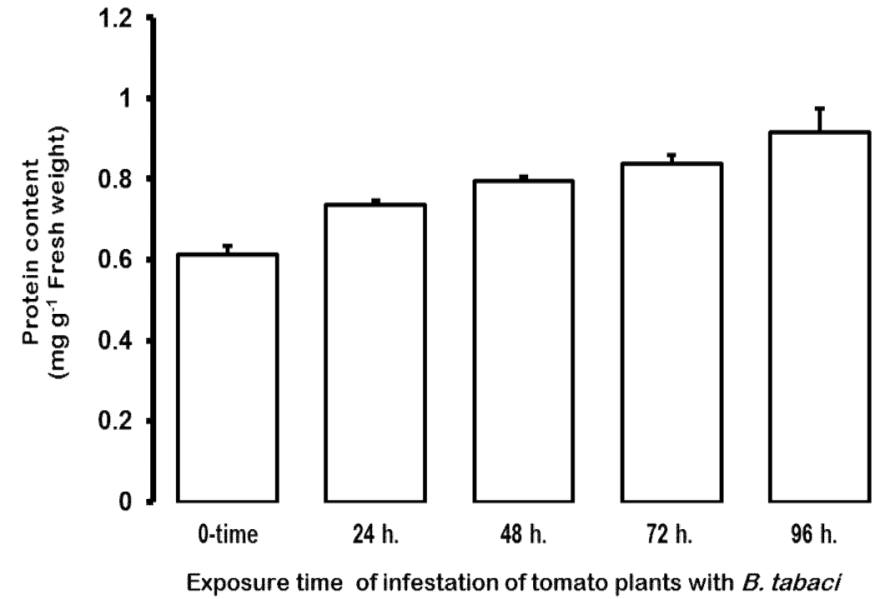

Figure 2: The effect of time-course on the leaf protein content in the infested tomato plants with the cotton whitefly B. tabaci.

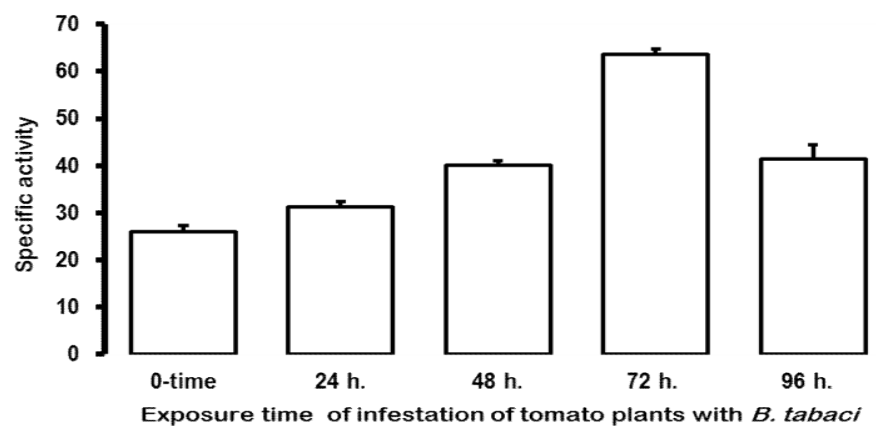

Figure 3: The effect of time-course on the specific activity of $\beta$-1,3-glucanase in infested tomato plants with the cotton whitefly $B$. tabaci. 


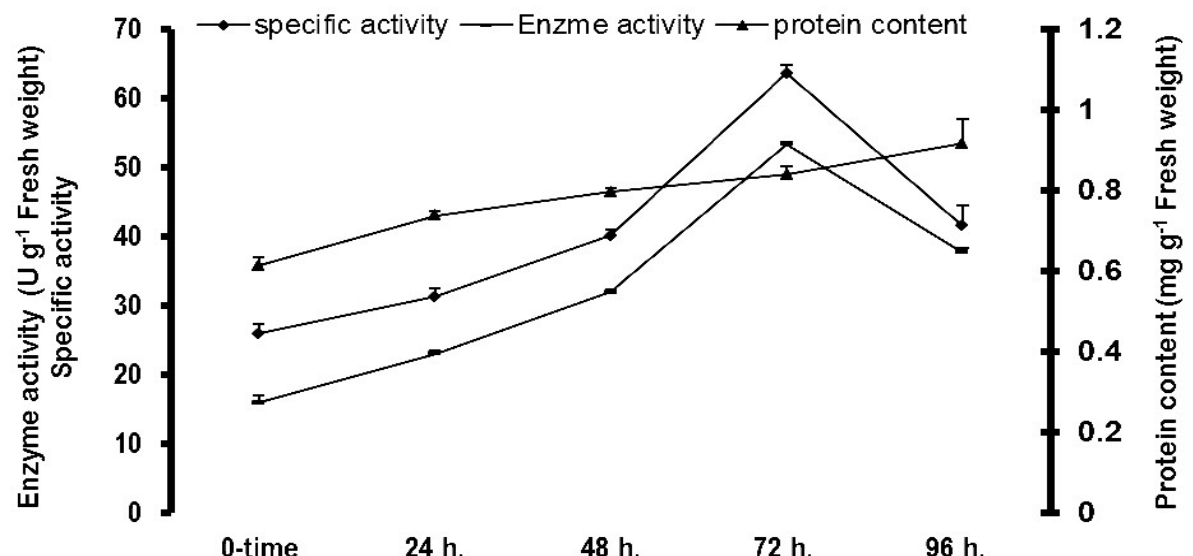

Exposure time of infestation of tomato plants with $B$. tabaci

Figure 4: The effect of time-course on enzyme activity and the specific activity of $\beta$-1,3-glucanase, and on leaf protein content in the infested tomato plants with the cotton whitefly $B$. tabaci.

2- The effect of $B$. tabaci infestation on chitinase in tomato plants:

Chitinase activity, specific activity and protein content which detected in whitefly-infested and noninfested leaf samples are shown in Table (2) and Figures (5 to 8).

The activity of chitinase of tomato leaves was found to be correlated with plant-whitefly interaction. The accumulation of chitinase started to increase with time one day after infestation (1.2 folds more than control). It had been recorded 0.006 $\mathrm{Ug}^{-1}$ fresh weight of $24 \mathrm{~h}$. infested tomato leaf, then gradually increased after $48,72 \mathrm{~h}$. (3.6 and 4.3 folds increase compared to control, respectively) and continued to accumulate and reached the maximum increase of $0.033 \mathrm{Ug}^{1}$ fresh weight of tomato leaf (6.1 folds more than control) at the fourth day. Except the $24 \mathrm{~h}$ infested plants, in all the treatments, the activity of chitinase increased significantly ( $\mathrm{p}=$ 0.05) than control (Figures, 5\&8).

Table 2: Time-course activity of chitinase and protein content in the infested tomato plants with the cotton whitefly $B$. tabaci.

\begin{tabular}{lccccc}
\hline \multirow{2}{*}{ Parameters } & \multicolumn{5}{c}{ Time in hours } \\
\cline { 2 - 6 } & $\mathbf{0 - t i m e}$ & $\mathbf{2 4}$ & $\mathbf{4 8}$ & $\mathbf{7 2}$ & $\mathbf{9 6}$ \\
\hline \multirow{2}{*}{ Chitinase activity } & $0.0054 \pm 3.18$ & $0.0066 \pm 7.58$ & $0.0197 \pm 9.01$ & $0.0230 \pm 1.38$ & $0.0330 \pm 8.65$ \\
& $\mathrm{D}$ & $\mathrm{D}$ & $\mathrm{C}$ & $\mathrm{B}$ & $\mathrm{A}$ \\
\hline \multirow{2}{*}{ Protein content } & $1.17 \pm 0.03$ & $1.28 \pm 0.018$ & $1.34 \pm 0.015$ & $1.39 \pm 0.023$ & $1.43 \pm 0.023$ \\
& $\mathrm{D}$ & $\mathrm{C}$ & $\mathrm{BC}$ & $\mathrm{AB}$ & $\mathrm{A}$ \\
\hline \multirow{2}{*}{ Specific activity } & $0.0046 \pm 3.38$ & $0.0041 \pm 1.18$ & $0.0146 \pm 6.67$ & $0.016 \pm 1$ & $0.023 \pm 1.46$ \\
& $\mathrm{C}$ & $\mathrm{C}$ & $\mathrm{B}$ & $\mathrm{B}$ & $\mathrm{A}$ \\
\hline
\end{tabular}

Values are means \pm S.E of 3 replicas.

Means followed by the same letter(s) within the same row are not significantly different at 0.05 probability level.

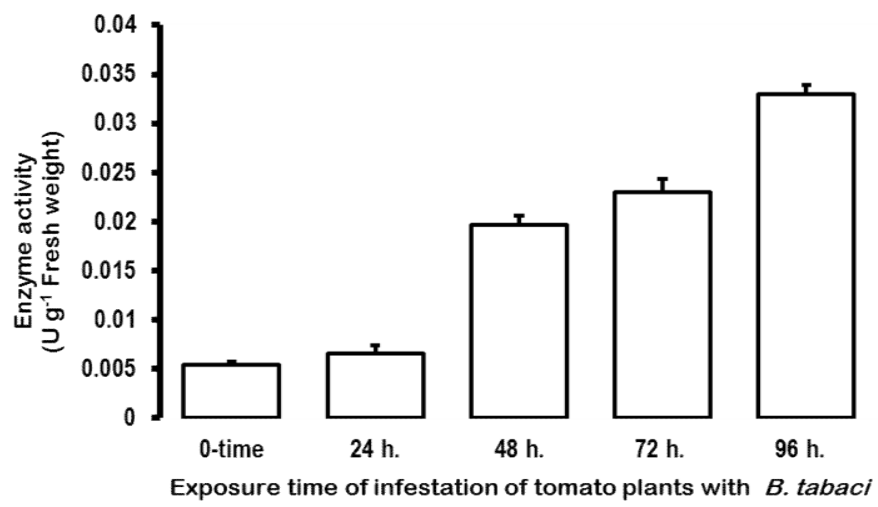

Figure 5: The effect of time-course on the enzyme activity of chitiase in the infested tomato plants with the cotton whitefly $B$. tabaci. 
As shown in Table (2) and Figures ( $6 \& 8)$, due to feeding by whitefly, total protein content in tomato leaf tissues was increased slowly at a steady pace. The total protein content was $1.28 \pm 0.018 \mathrm{mg}$ $\mathrm{g}^{-1}$ fresh weights one day after infestation which was 1.09 folds more than control $\left(1.17 \pm 0.03 \mathrm{mg} \mathrm{g}^{-1}\right.$ fresh weight) (Fig.6). Protein content continued to climb by the time and reached the maximum $(96 \mathrm{~h}$ after infestation; $1.43 \pm 0.02 \mathrm{mg} \mathrm{g}^{-1}$ fresh weight) but there were no significant differences between plants that exposed to whitefly for $96 \mathrm{~h}$ and $72 \mathrm{~h}$. or between $72 \mathrm{~h}$. and $48 \mathrm{~h}$ whitefly-infested plants (Fig. 6).

Such as chitinase activity, specific activity has the same trend. It increased significantly after $48 \mathrm{~h}$. of whitefly feeding and continued in elevation with time until it reached the maximum in the fourth day of feeding. Comparing to 0-time, specific activity of chitinase was significantly higher in plant exposed to whitefly for 48, 72 and $96 \mathrm{~h}$. (Table 2 and Figures, 7 \& 8); it was observed that specific activity of chitinase decreased after one day of infestation $(0.0041)$ but there were no significant differences between plants that exposed to whitefly for $24 \mathrm{~h}$ and control, also there was no significant difference between plants that exposed to whitefly for $48 \mathrm{~h}$ and $72 \mathrm{~h}$. in their specific activities $(0.0146$ and 0.0160 respectively). The chitinase specific activity of tomato plants exposed to whitefly for 96 $\mathrm{h}$ was significantly higher than others.

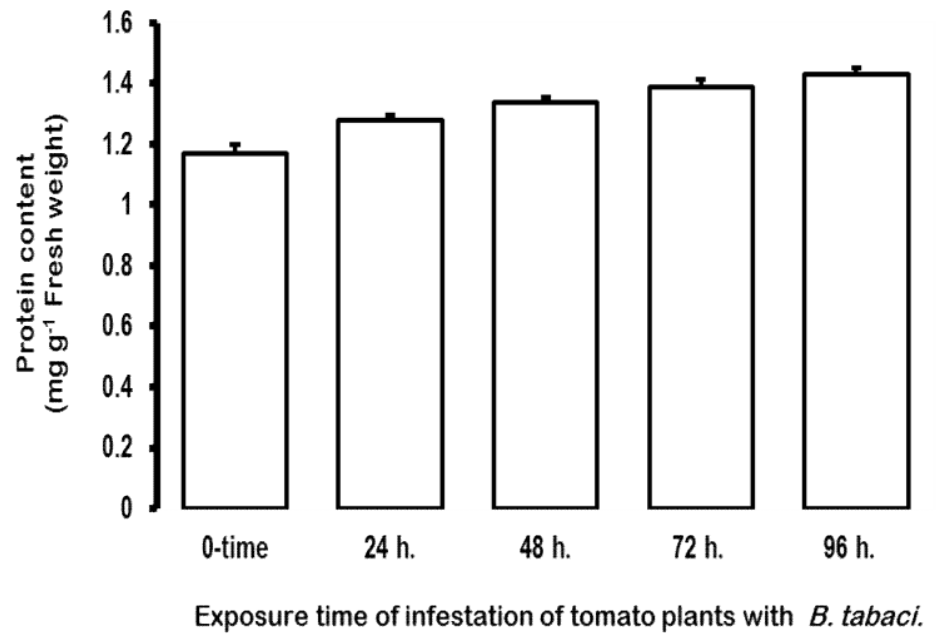

Figure 6: The effect of time-course on the leaf protein content in the infested tomato plants with the cotton whitefly $B$. tabaci.

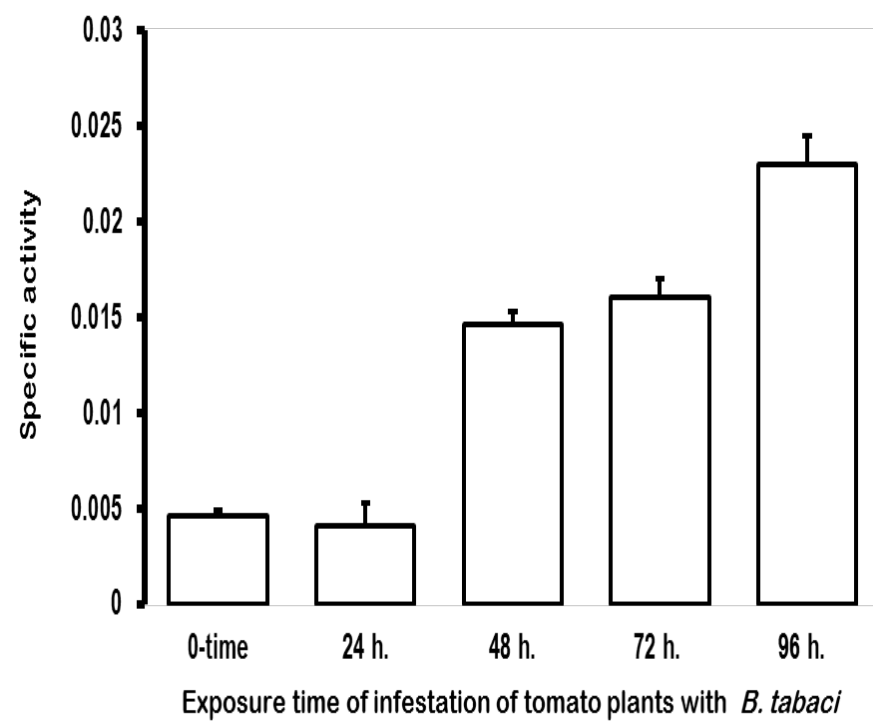

Figure 7: The effect of time-course on the specific activity of chitinase in the infested tomato plants with the cotton whitefly $B$. tabaci. 


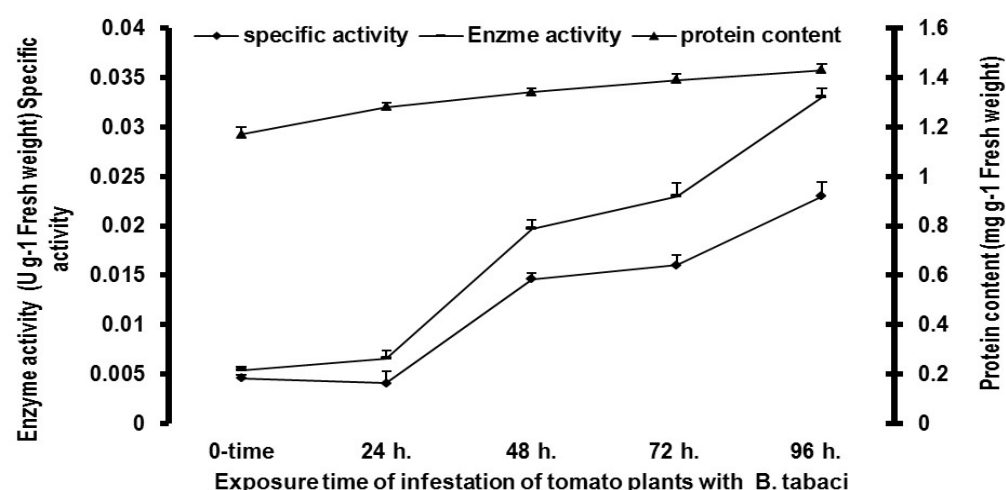

Figure 8: The effect of time-course on enzyme activity and the specific activity of chitinase, and on leaf protein content in the infested tomato plants with the cotton whitefly $B$. tabaci.

3- The effect of $B$. tabaci infestation on polyphenol oxidase activity in tomato plants:

Polyphenol oxidase activity, specific activity and protein content for whitefly infested and noninfested tomato leaf samples are illustrated in Table (3) and Figures (9, $10 \& 11)$. Table (3) showed that in all treatments, polyphenol oxidase activity after $24,48,72$ or $96 \mathrm{~h}$. of whitefly infestation increased more than 0 -time. It was found that the activity increased substantially after $24 \mathrm{~h}$. of feeding of whitefly $\left(26 \mathrm{Ug}^{-1}\right.$ fresh weight $=4.3$ folds more than control). Subsequently the enzyme activity retreated gradually after 48,72 and $96 \mathrm{~h}$. of infestation (2.7, 2.1 and 1.5 folds more than control respectively).
There were significant differences among all treatments in Polyphenol oxidase activity. No significant difference was observed in enzyme activities between $96 \mathrm{~h}$ whitefly-exposed plants and non-infested plants.

Specific activity of polyphenol oxidase had the same trend of the enzyme activity (Table, 3 and figures $10 \& 11$ ). It was found that specific activity reached the highest value after $24 \mathrm{~h}$ of feeding (20.26) and it was significantly higher than any exposure time, then it retracted significantly during the $2^{\text {nd }}, 3^{\text {rd }}$ and $4^{\text {th }}$ days after infestation $(12.23,9.14$ and 6.34 , respectively).

Table 3: Time-course activity of polyphenol oxidase and protein content in the infested tomato plants with the cotton whitefly $B$. tabaci.

\begin{tabular}{lccccc}
\hline \multirow{2}{*}{ Parameters } & \multicolumn{5}{c}{ Time in hours } \\
\cline { 2 - 6 } & $\mathbf{0 - t i m e}$ & $\mathbf{2 4}$ & $\mathbf{4 8}$ & $\mathbf{7 2}$ & $\mathbf{9 6}$ \\
\hline \multirow{2}{*}{ Polyphenol activity } & $6 \pm 0.76$ & $26 \pm 0.87$ & $16.33 \pm 0.93$ & $12.67 \pm 0.88$ & $9.17 \pm 1$ \\
& $\mathrm{D}$ & $\mathrm{A}$ & $\mathrm{B}$ & $\mathrm{C}$ & $\mathrm{D}$ \\
\hline \multirow{2}{*}{ Protein content } & $1.17 \pm 0.03$ & $1.28 \pm 0.018$ & $1.34 \pm 0.015$ & $1.39 \pm 0.023$ & $1.43 \pm 0.023$ \\
& $\mathrm{D}$ & $\mathrm{C}$ & $\mathrm{BC}$ & $\mathrm{AB}$ & $\mathrm{A}$ \\
\hline \multirow{2}{*}{ Specific activity } & $5.19 \pm 0.72$ & $20.26 \pm 0.46$ & $12.23 \pm 0.79$ & $9.14 \pm 0.69$ & $6.34 \pm 0.7$ \\
& $\mathrm{D}$ & $\mathrm{A}$ & $\mathrm{B}$ & $\mathrm{C}$ & $\mathrm{D}$ \\
\hline
\end{tabular}

Values are means \pm S.E of 3 replicas.

Means followed by the same letter(s) within the same row are not significantly different at 0.05 probability level.

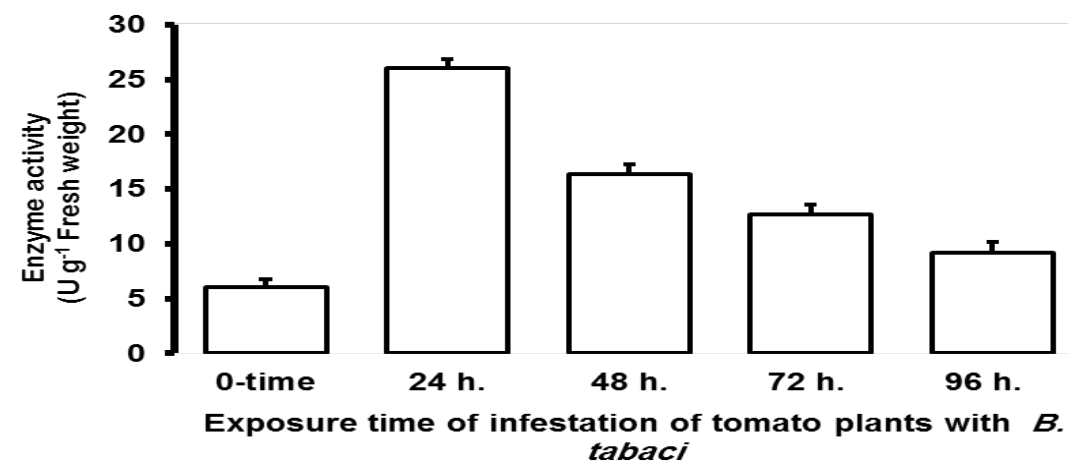

Figure 9: The effect of time-course on the enzyme activity of polyphenol oxidase in the infested tomato plants with the cotton whitefly $B$. tabaci. 


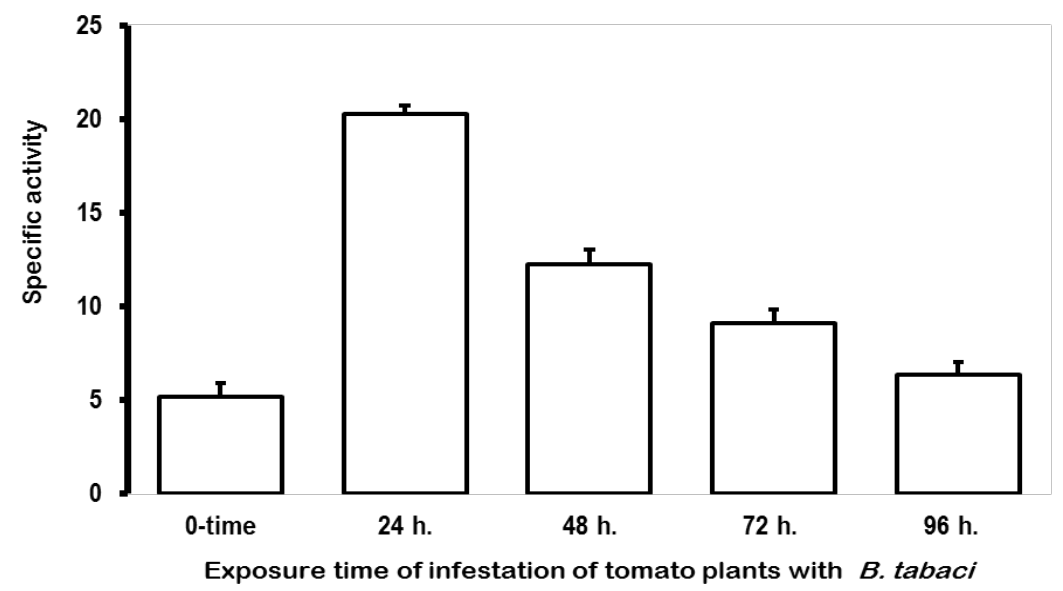

Figure 10: The effect of time-course on the specific activity of polyphenol oxidase in infested tomato plants with the cotton whitefly $B$. tabaci.

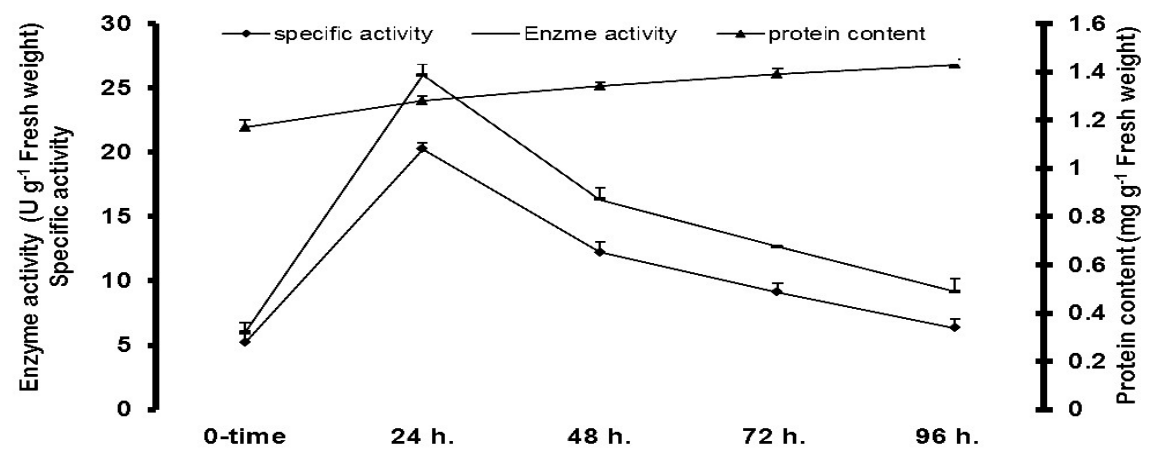

Exposure time of infestation of tomato plants with $B$. tabaci

Figure 11: The effect of time-course on enzyme activity and the specific activity of polyphenol oxidase, and on leaf protein content in the infested tomato plants with the cotton whitefly $B$. tabaci.

There were significant differences among all treatments in polyphenol oxidase specific activities but there was no significant difference found on specific activity between 0 -time treatment and $96 \mathrm{~h}$ infested plants.

4- The effect of $B$. tabaci infestation on peroxidase activity in tomato plants:

Table (4) and figures (12 \& 14) illustrate the peroxidase activity in tomato plants induced by

Table 4: Time-course activity of peroxidase in the infested tomato plants with the cotton whitefly B. tabaci.

\begin{tabular}{lccccc}
\hline \multirow{2}{*}{ Parameters } & \multicolumn{5}{c}{ Time in hours } \\
\cline { 2 - 6 } & 0-time & $\mathbf{2 4}$ & $\mathbf{4 8}$ & $\mathbf{7 2}$ & $\mathbf{9 6}$ \\
\hline \multirow{2}{*}{ Peroxidase activity } & $924.67 \pm 31.02$ & $1518 \pm 60.1$ & $1648.67 \pm 37.02$ & $1252.67 \pm 31.29$ & $1179.33 \pm 20.72$ \\
& $\mathrm{D}$ & $\mathrm{B}$ & $\mathrm{A}$ & $\mathrm{C}$ & $\mathrm{C}$ \\
\hline \multirow{2}{*}{ Protein content } & $1.17 \pm 0.03$ & $1.28 \pm 0.018$ & $1.34 \pm 0.015$ & $1.39 \pm 0.023$ & $1.43 \pm 0.023$ \\
& $\mathrm{D}$ & $\mathrm{C}$ & $\mathrm{BC}$ & $\mathrm{AB}$ & $\mathrm{A}$ \\
\hline \multirow{2}{*}{ Specific activity } & $795.1 \pm 47.21$ & $1183.72 \pm 53.68$ & $1234.31 \pm 41.21$ & $904.62 \pm 37.37$ & $827.31 \pm 24.09$ \\
& $\mathrm{~B}$ & $\mathrm{~A}$ & $\mathrm{~A}$ & $\mathrm{~B}$ & $\mathrm{~B}$ \\
\hline
\end{tabular}

Values are means \pm S.E of 3 replicas.

Means followed by the same letter(s) within the same row are not significantly different at 0.05 probability level. 
Statistically, peroxidase activities in tomato plants which exposed to whitefly feeding for 24, 48 and $72 \mathrm{~h}$ were significantly different compared to the control (0-time). There was no significant difference between $72 \mathrm{~h}$ and $96 \mathrm{~h}$ whitefly-exposed plants in the enzyme activity

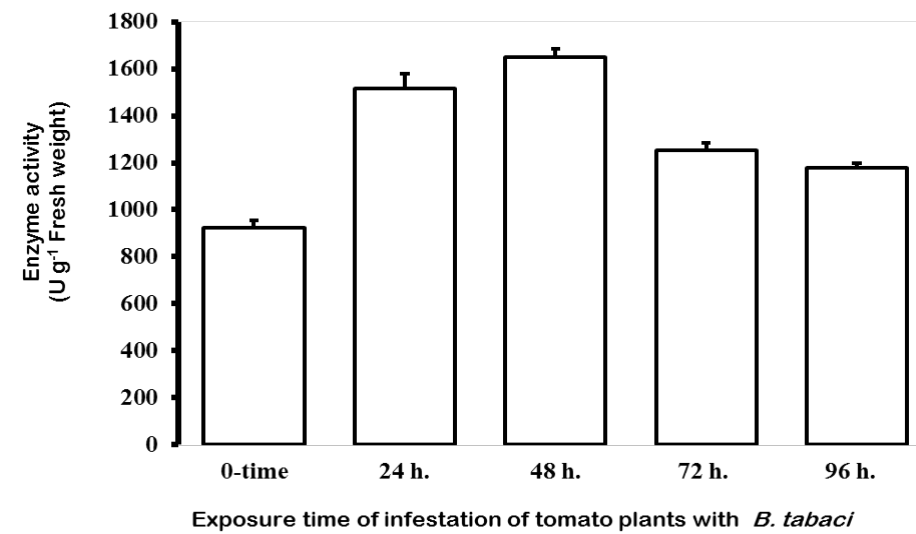

Figure 12: The effect of time-course on the enzyme activity of peroxidase in the infested tomato plants with the cotton whitefly $B$. tabaci.

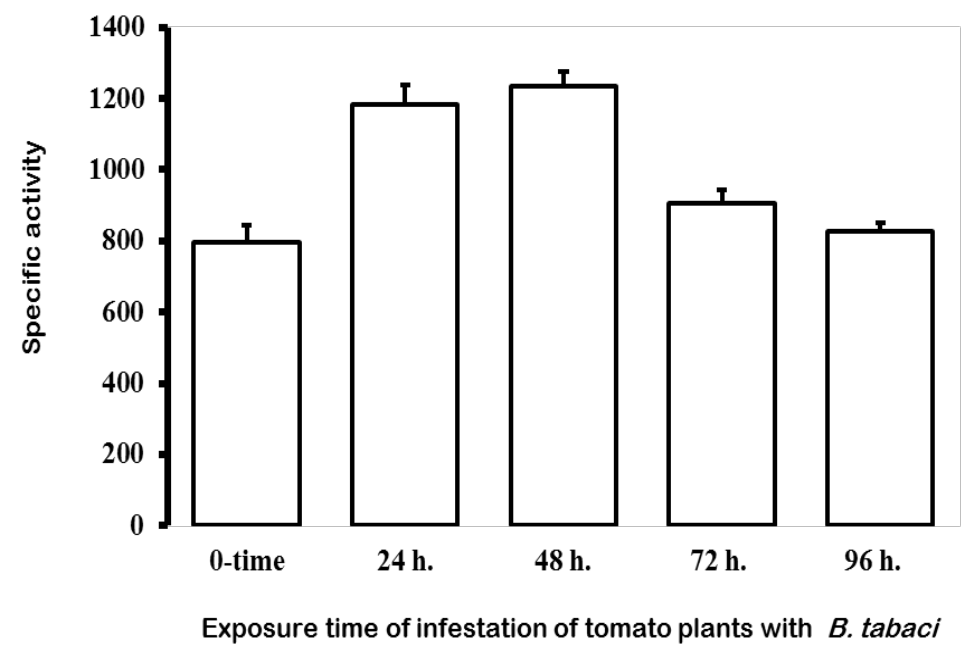

Figure 13: The effect of time-course on the specific activity of peroxidase in the infested tomato plants with the cotton whitefly $B$. tabaci.

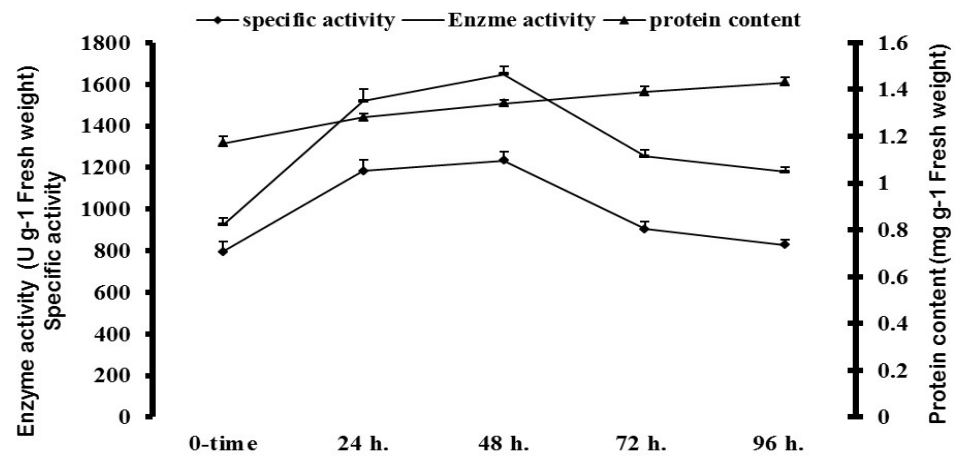

Exposure time of infestation of tomato plants with B. tabaci

Figure 14: The effect of time-course on enzyme activity and the specific activity of peroxidase, and on leaf protein content in the infested tomato plants with the cotton whitefly $B$. tabaci. 
The peroxidase specific activity reached $1183.72 \mathrm{Ug}^{-1}$ fresh weight after $24 \mathrm{~h}$ of whitefly feeding on tomato leaves. It elevated to the maximum of $1234.31 \pm 41.21$ (1.5 folds greater than control) in $48 \mathrm{~h}$ infested-tomato plants (Figures, $13 \& 14)$, then it decreased after 72 , and $96 \mathrm{~h}$. of infestation (1.1 and 1.04 folds respectively more than control).

There was no significant difference between peroxidase specific activity in 24 and $48 \mathrm{~h}$. infested tomato plants. Also, no significant differences were observed among specific activities of $72,96 \mathrm{~h}$. whitefly-exposed plants and control.

Figure (15) illustrates the comparative activities of $\beta$-1, 3-glucanase, chitinase, polyphenol oxidase and peroxidase within four days of $B$. tabaci infestation. The activity of $\beta-1, \quad 3$-glucanase increased gradually to reach to the maximal value at the $3^{\text {rd }}$ day of $B$. tabaci infestation. The activity of chitinase increased gradually in a positive correlation with the time of whitefly infestation. The activity of polyphenol oxidase reached to the maximal value after $24 \mathrm{~h}$ of $B$. tabaci infestation then gradually decreased. The peroxidase activity slightly increased and reached the maximal value after $48 \mathrm{~h}$. of $\mathrm{B}$. tabaci infestation then gradually decreased.

5- PR proteins in tomato plant induced resistance to $B$. tabaci infestation.

Table (5) illustrates that the maximum increase of the mean number of whitefly adults $/ \mathrm{cm}^{2}$ of tomato leaf $\left(7.8 \pm 0.1\right.$ adults $\left./ \mathrm{cm}^{2}\right)$ was recorded in untreated tomato plants after $48 \mathrm{~h}$. of whitefly infestation. The obtained results revealed a remarkable decrease in the mean numbers of whitefly adults $/ \mathrm{cm}^{2}$ of tomato leaf to reach the minimal mean number of whitefly adults $/ \mathrm{cm}^{2}$ of tomato leaf $\left(7.1 \pm 0.13\right.$ adults $\left./ \mathrm{cm}^{2}\right)$ in untreated tomato plants after $96 \mathrm{~h}$ of whitefly infestation. The mean number of whitefly adults $/ \mathrm{cm}^{2}$ of untreated tomato plants was $7.4 \pm 0.16$ adults $/ \mathrm{cm}^{2}$ (Figure, 16). The mean numbers of whitefly adults $/ \mathrm{cm}^{2}$ of artificially wounded or pre-infested tomato plants with $B$. tabaci were significantly decreased to reach $6.6 \pm 0.14$ adults $/ \mathrm{cm}^{2}$ or $6.5 \pm 0.15$ adults $/ \mathrm{cm}^{2}$ respectively (Table 5 and Figure 16).

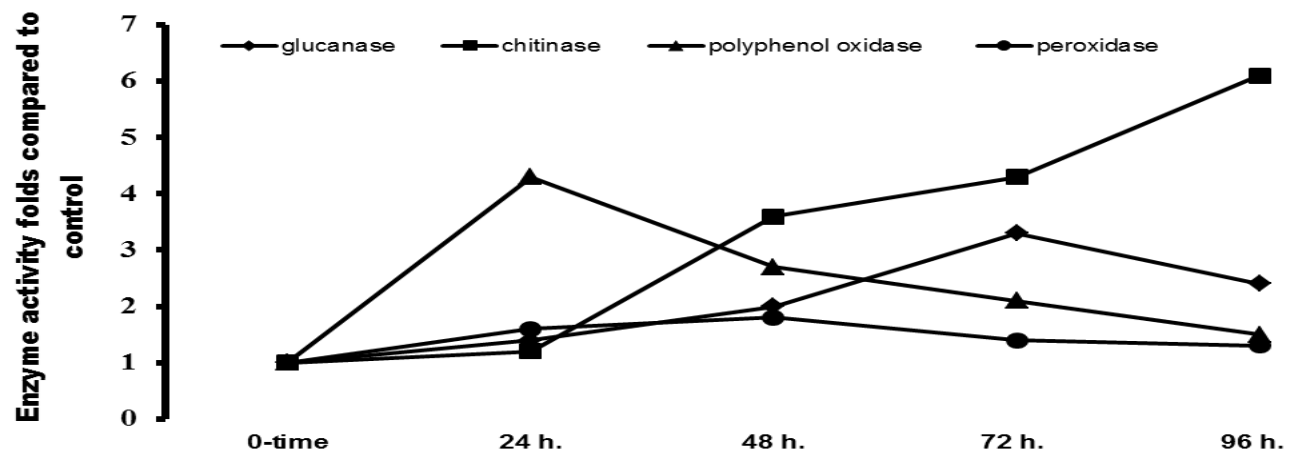

Exposure time of infestation of tomato plants with B. tabaci

Figure 15: The effect of time-course on enzyme activity of $\beta$-1, 3-glucanase, chitinase, polyphenol oxidase and peroxidase in the infested tomato plants with the cotton whitefly $B$. tabaci.

Table 5: The effect of artificially wounded, whitefly pre-infested and pretreated tomato plants with Pseudomonas spp. on the mean numbers of whitefly adults $/ \mathrm{cm}^{2}$.

\begin{tabular}{|c|c|c|c|c|c|}
\hline \multirow{2}{*}{ Treatment } & \multicolumn{4}{|c|}{ Time in hours } & \multirow{2}{*}{ Means } \\
\hline & 24 & 48 & 72 & 96 & \\
\hline Control & $7.6 \pm 0.35$ & $7.8 \pm 0.1$ & $7.2 \pm 0.24$ & $7.1 \pm 0.13$ & $7.4 \pm 0.16 \mathrm{~A}$ \\
\hline Wounded & $6.3 \pm 0.3$ & $6.7 \pm 0.3$ & $6.4 \pm 0.19$ & $6.9 \pm 0.19$ & $6.6 \pm 0.14 \mathrm{~B}$ \\
\hline Pre-infested & $6.5 \pm 0.37$ & $6.4 \pm 0.34$ & $6.2 \pm 0.29$ & $6.9 \pm 0.19$ & $6.5 \pm 0.15 \mathrm{~B}$ \\
\hline P. fluorescens & $4.8 \pm 0.15$ & $5.4 \pm 0.22$ & $5.7 \pm 0.18$ & $4.7 \pm 0.19$ & $5.1 \pm 0.14 \mathrm{C}$ \\
\hline P. chlororaphis & $4.9 \pm 0.1$ & $4.3 \pm 0.16$ & $4.8 \pm 0.19$ & $4.7 \pm 0.14$ & $4.7 \pm 0.13 \mathrm{D}$ \\
\hline Means & $6.3 \pm 0.41 \mathrm{~A}$ & $6.3 \pm 0.73 \mathrm{~A}$ & $6.2 \pm 0.5 \mathrm{~A}$ & $6.4 \pm 0.57 \mathrm{~A}$ & \\
\hline
\end{tabular}

Values are means \pm S.E of 4 replicas.

Means followed by the same letter(s) are not significantly different at 0.05 probability level. 


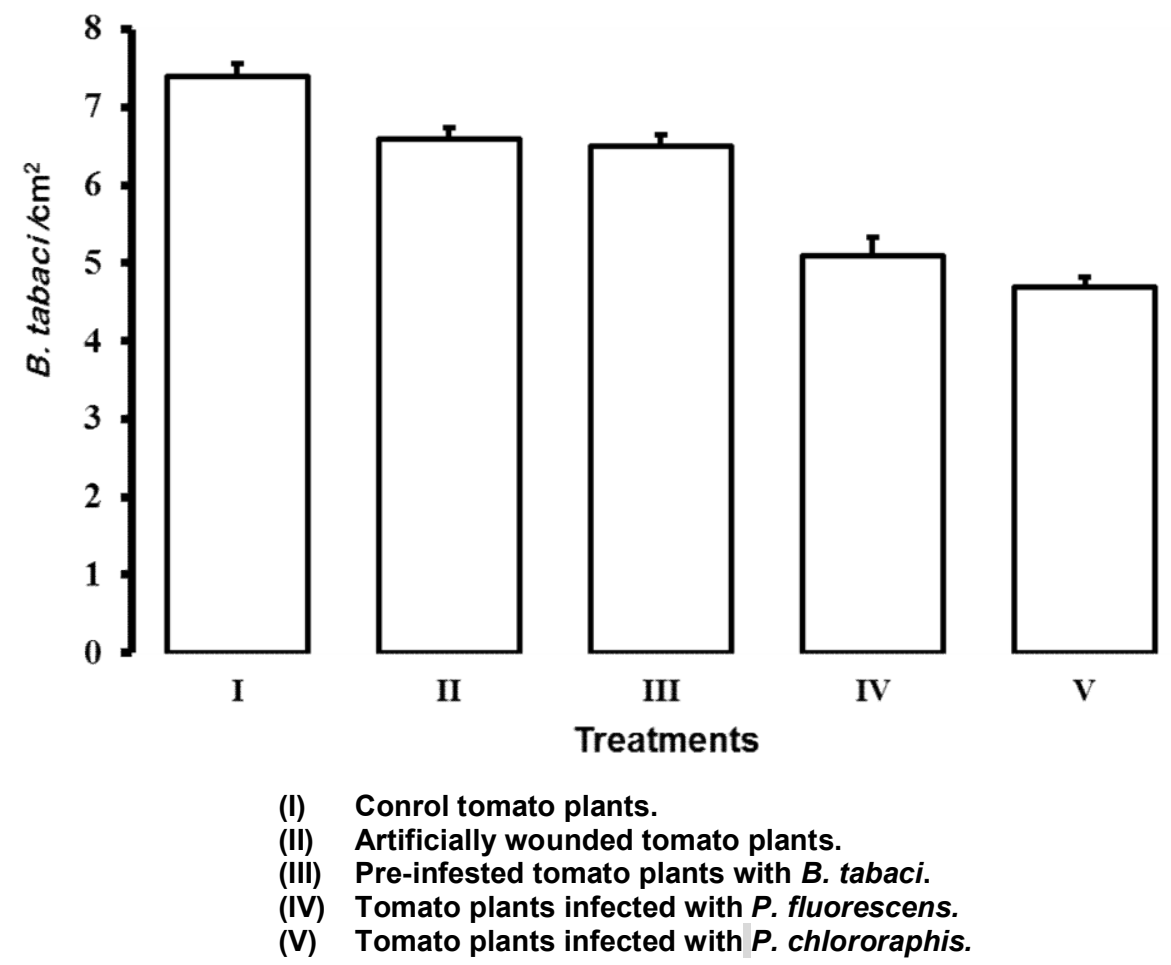

Figure 16: The effect of artificially wounded, whitefly pre-infested and pretreated tomato plants with Pseudomonas spp. on the mean numbers of whitefly adults $/ \mathrm{cm}^{2}$.

Treatment of tomato plants with P. fluorescens reduced the mean numbers of whitefly adults $/ \mathrm{cm}^{2}$ by $31.1 \%$, while $P$. chlororaphis reduced the mean numbers of whitefly adults $/ \mathrm{cm}^{2}$ by $36.5 \%$ (Table 5 and Figure 16). As shown in Table 5, significant differences in the mean numbers of whitefly adults $/ \mathrm{cm}^{2}$ of tomato leaf were observed among all treatments except between artificially wounded and pre-infested tomato plants with B. tabaci.

From the obtained results, it seems clearly that the PR proteins play an important defensive role against whiteflies. Artificially wounded tomato plants reduced the mean numbers of whitefly adults $/ \mathrm{cm}^{2}$ by about $10.8 \%$, while the biological agent $P$. chlororaphis (non-pathogens bacteria) reduced the mean numbers of whitefly adults $/ \mathrm{cm}^{2}$ by about $36.5 \%$.

\section{DISCUSSION}

Jimencz et al., (1995) was the first to report on PR proteins resulting from feeding by $B$. tabaci. The present results are in conformity with the findings obtained by Inbar et al., (1999b). They declared that feeding of leaf miner and $B$. argentifolii induced local and systemic production of putative defensive proteins, and lysozymes in tomato plants. Mayer et al., (1997) proved that the induction of $\beta$ 1,3-glucanases and other PR-proteins in tomato plants infested with Bemisia argentifolii begun 2 to 3 days after feeding starts and enzyme levels increased for 3 to 4 weeks. Also, Antony and Palaniswami (2006) reported that cassava plants fed upon by whitefly $B$. tabaci showed increased levels of PR proteins as compared to non-infested plants. The enzyme specific activities increased from 2 to 7 folds and protein content in leaf extracts decreased in whitefly-infested plants, compared to noninfested plants. Also, Bi and Felton. (1995) reported that the activity of several enzymes increased after insect infestation. Inbar et al. (1999a) declared that feeding of whiteflies induced high levels of PR proteins that were considered to play defensive roles against insect pests. Srinivasan and Uthamasamy, (2004) reported that the induction of PR proteins such as chitinase, and $\beta$-1,3-glucanase in tomato began after $72-96 \mathrm{~h}$. of feeding by whitefly $B$. tabaci.

A companied with our results, Taggar et al., (2012) demonstrated that $B$. tabaci infestation increased the activities of peroxidase activity in black gram, (Vigna mungo) and suggested that the enhanced activities of the enzymes might contribute to bio-protection of black gram plants against $B$. tabaci infestation. Puthoff et al., (2010) reported that B. tabaci and Trialeurodes vaporariorum evoked similar changes in tomato wound- and defense-response gene expression. The levels of RNAs ethylene-regulated genes that encode the basic $\beta$-1,3-glucanase $(G l u B)$ and basic chitinase (Chi9), were abundant in infested leaves from the 
time nymphs initiated feeding. In addition, $G l u B$ RNAs accumulated in apical non-infested leaves. PR protein-1 RNAs also accumulated after whitefly feeding. McKenzie et al., (2002) declared that PR protein $(\beta$-1,3-glucanase, chitinase, peroxidase, $\mathrm{P} 2$ and $\mathrm{P} 4)$ response was much vigorous when it was attacked by whiteflies hosting tomato mottle virus (ToMoV) than by whitefly alone.

Graham and Stichlen, (1994) reported that induction of PR proteins such as chitinases, peroxidascs and $\beta$-1-3-glucanase has bad impact on pathogens and insect pests. Chitinase debases chitin, a considerable ingredient of insect cell. Chitinase may extremely influence insects by harming the peritrophic membrane (chitin-based structures) that provides a boundary to ingested pathogens and other material that pose a threat to the insect. Chitinases can moreover act as inhibit amylase activity and meddled with assimilation of plant parts (Ary et al., 1989). It may also increase vulnerability of the insects to biological control agents. Chitinase activity may interfere with insect growth and nourishing, encourage microbial infection, and finally cause death (Shapiro et al., 1987; Wang et al., 1996). Following pathogen and insect attack, tomato plants start in induction of Peroxidases. Peroxidases are implicated in production and polymerization of phenolics and hypersensitive reactions, limiting the chance of disease dispersal (Bowles, 1990). Peroxidases moreover have passive influence on food edible and protein accessibility to herbivorous insects (Duffey and Stout, 1996).

The harmfulness of phenolics such as chlorogenic acid has been habitually ascribed to their tendency to be oxidized enzymatically by means of polyphenol oxidase (PPO), or peroxidase (POD) a process which improves the anti-insect action of phenolics by creating highly reactive $o$ quinones (Felton et al., 1989; Appel, 1993). This oxidation forms quinones that covalently tie to proteins, in this way constraining their bioavailability as nutrients, and may form reactive oxygen species (e.g., superoxide radical and $\mathrm{H}_{2} \mathrm{O}_{2}$ ) that harm fundamental supplements or indispensable molecules such as lipids, proteins, and nucleic acids; this is the basis of the anti-nutritive function of PPO against insects. (Felton et al., 1989, 1992; Appel, 1993; Summers and Felton, 1994). Cysteine, lysine, histidine, and methionine residues are preferentially alkylated, which prevents their assimilation (Felton et al., 1992, Hurrell and Finot 1984). As these are essential amino acids, a diet rich in PPO can lead to nutritional deficiencies and a suppression of larval growth (Felton et al. 1989, Duffey and Stout 1996). In tomato, the importance of PPO in defense was confirmed by the finding that it is induced by the tomato herbivore defense signal systemin (Constabel et al., 1995).
Endorsement with present study, it is well established that insect injury as well as pathogen onslaught can obviously induce PR proteins (Stout et al., 1994; Stout et al., 1995; Stout and Duffey, 1995). Dowd and Lagrimini (2006) found that the number of adult whiteflies of $T$. vaporariorum per plant was significantly reduced on high peroxidase infested plants compared to wild type plants. Wounding and herbivore damage cause rapid increases in jasmonic acid (Stout and Bostock, 1999; Reymond et al., 2000), triggering systemic defenses against herbivores and pathogens. Plants are equipped with a range of defense mechanisms against herbivorous insects. Moreover, feeding damage to plants by insect herbivores induces the production of plant volatiles, which are attractive to the herbivore's natural enemies (Girling et al., 2008).

On the other hand, plants can gain immunity against diseases through various biological factors including necrotizing pathogens, non-pathogens and soil born rhizosphere bacteria and fungi (Van loon et al., 1998). Enkerli et al., (1993) found that chitinase activity was increased systemically by the infection of tomato plants with Phytophthora infestans. Ren, and West (1992) reported that Pseudomonas pretreated plants resulted in an additional increase in PR proteins. Fluorescent pseudomonads are non-pathogenic rhizobacteria (Saravanan et al., 2004; Karthikeyan et al., 2006) and various isolates of Pseudomonas fluorescens, repressed the soil borne pathogens via several suggested mechanisms (Karthikeyan et al., 2006). Previous studies showed the ability of Pseudomonas spp. to promote a few biochemical metabolic changes enhancing insect control. Ardebili et al., (2011) reported that tomato seed bacterization by $P$. fluorescens remarkably prompt peroxidase, polyphenoloxisae and superoxid dismutase activities in root tissues. It is well established that Pseudomonas spp. increased physical and mechanical strength of the host cellwall and causing biochemical and physiological changes leading to synthesis of PR proteins (van Loon, 1999; Kim, et al., 2001; Ramamoorthy and Samiyappan, 2001).

These results provide clear evidence that tomato plants resistance is depend on a set of protecting systems against different pests. Wounding, insect infestation and infection of tomato plants with Pseudomonas spp. cause rapid trigger systemic defenses against herbivores and pathogens. In addition, these results provide several insights into the integration and coordination of the induced defenses of tomato plants against multiple pests and suggest that the expression of resistance against some pests may compromise resistance to others. The obtained results of the present study will help in developing a plan of pest management 
program for $B$. tabaci under greenhouse conditions. When tomato plants pretreated with the biological agent Pseudomonas chlororaphis (non-pathogens bacteria), the numbers of $B$. tabaci adults $/ \mathrm{cm}^{2}$ on tomato plant leaves were dramatically reduced.

\section{REFERENCES}

Antoniw, J.F. and White, R.F. (1980). The effects of aspirin and polyacrylic acid on soluble leaf proteins and resistance to virus infection in five cultivars of tobacco. Journal of Phytopathology, 98: 331-341.

Antony, B. and Palaniswami, M.S. (2006) Bemisia tabaci feeding induces pathogenesis-related proteins in cassava (Manihot esculenta Crantz). Indian Journal of Biochemistry and Biophysics, 43 (3): 182-185.

Ardebili, Z.O., Ardebili, N.O. and Hamdi, S.M.M. (2011). Physiological effects of Pseudomonas fluorescens CHA0 on tomato (Lycopersicon esculentum Mill.) plants and its possible impact on Fusarium oxysporum f. sp. Lycopersici. Australian Journal of Crop Scince, 5 (12): 1631-1638.

Appel, H. M.(1993). Phenolics in ecological interactions: the importance of oxidation. Journal of Chemical Ecolology, 19: 15211552.

Ary, M.B., Richardson, M., and Shewry, P.R. (1989). Purification and characterization of an insect a-amylase inhibitor/endochitinase from seeds of Job's tears (Coix lachrymajobi). Biochemistry and Biophysics Acta, 999 (3): 260-266.

Bi, J.L. and Felton, G.W. (1995). Foliar oxidative stress and insect herbivory: Primary compounds, secondary metabolites, and reactive oxygen species as components of induced resistance. Journal of Chemical Ecology, 21 (10): 1511-1530.

Bol, J.F., Linthorst, H.J.M., Cornelissen, B.J.C. (1990). Plant pathogenesis-related proteins induced by virus infection. Annual Review of Phytopathology, 28: 113-138.

Bowles, D.J. (1990). Defense-related proteins in higher plants. Annuual Review of Biochemistry, 59: 873-907.

Bradford, M.M. (1976). A rapid and sensitive method for the quantitation of microgram quantities of protein utilizing the principle of protein-dye binding. Analytical Biochemistry, 72: 248-254.

Brederode, F.T., Linthorst, H.J.M. and Bol, J.F. (1991). Differential induction of acquired resistance and PR gene expression in tobacco by virus infection, ethephon treatment, UV light and wounding. Plant Molecular Biology, 17: 1117-1125.
Carr, J.P.and Klessig, D.F. (1989). The pathogenesis-related proteins of plants. In: Setlow, J.K. (ed.) Genetic Engineering: Principle and Methods, Plenum Press, New York, pp. 65-109.

Constabel, C.P.; Bergey, D. and Ryan, C.A. (1995) Systemin activates synthesis of woundinducible tomato leaf polyphenol oxidase via the octadecanoid defense signaling pathway. Proceedings of the National Academy of Sciences. USA 92: 407-411.

Diaz, J. and Merino, F. (1998). Wound-induced shikimate dehydrogenase and peroxidase related to lignification in pepper (Capsicum annuum L.) leaves. Journal of Plant Physiology,152 (1): 51-57

Dowd, P.F. and Lagrimini, L.M. (2006). Examination of the biological effects of high anionic peroxidase production in tobacco plants grown under field conditions. I. Insect Pest Damage. Transgenic Research, 15 (2):197-204.

Duffey, S.S. and Stout, M.J. (1996). Antinutritive and toxic compounds of plant defense against insects. Archives of Insect Biochemistry and Physiology, 32 (1): 3-37.

Enkerli, J., Gisi, U. and Mösinger, E. (1993). Systemic acquired resistance to Phytophthora infestans in tomato and the role of pathogenesis related proteins. Physiological and Molecular Plant Pathology, 43 (3): 161171.

Felton, G.W., Donato, K., Vecchio, R.J.D. and Duffey, S.S. (1989). Activation of plant foliar oxidases by insect feeding reduces nutritive quality of foliage for noctuid herbivores. Journal of Chemical Ecolology, 15 (12): 2667-2694.

Felton, G. W.; Donato, K.; Broadway, R. M. and Duffey, S. S. (1992). Impact of oxidized plant phenolics on the nutritional quality of dietary protein to a noctuid herbivore, Spodoptera exigua. Journal of Insect Physiology, 38: 275-285

Girling, R.D., Madison, R., Hassall, M., Poppy, G.M. and Turner, J.G. (2008). Investigations into plant biochemical wound-response pathways involved in the production of aphid-induced plant volatiles. Journal of Experimental Botany, 5 (11): 3077-3085.

Graham, L.S., and Sticklen, M.B. (1994). Plant chitinases. Canadian Journal of Botony, 72: 1057-1083. 
Hammerschmidt, R., Nuckles, E.M. and Kuc, J. (1982). Association of enhanced peroxidase activity with induced systemic resistance of cucumber to Colletotrichum lagenarium. Physiological Plant Pathology, 20 (1): 73-76.

Hurrell, R.F. and Finot P.A. (1984) Nutritional consequences of the reactions between proteins and oxidized polyphenolic acids. In: Friedman M (ed) Nutritional and Toxicological Aspects of Food Safety. Plenum Press, New York, NY,: 423-435. ISBN 0-306-41708-1

Inbar, M., Doostdar, H. and Mayer, R.T. (1999a). Effects of sessile whitefly nymphs (Homoptera: Aleyrodidae) on leaf-chewing larvae (Lepidoptera: Noctuidae). Physiological and Chemical Ecology, 28 (3): 353-357.

Inbar, M., Doostdar, H., Leibee, G.L. and Mayer, R.T. (1999b). The role of plant rapidly induced responses in asymmetric interspecific interactions among insect herbivores. Journal of Chemical Ecology, 25 (8): 1961-1979.

Inbar, M., Doostdar, H., Sonoda, R.M., Leibee, G.L. and Mayer, R.T. (1998). Elicitors of plant defensive systems reduce insect densities and disease incidence. Journal of Chemical Ecology, 24 (1):135-149.

Jiméncz, D.R., Yokomi, R.K, Mayer, R.T. and Shapiro, J.P. (1995). Cytology and physiology of silverleaf whitefly-induced squash silverleaf. Physiological and Molecular Plant Pathology, 46 (3): 227-242.

Karban, R. and Baldwin, I.T. (1997). Induced responses to herbivory. Chicago: University of Chicago Press, 319.

Karthikeyan, M., Radhika, K., Mathiyazhagan, S., Bhaskaran,R., Samiyappan, R., Velazhahan, R. (2006). Induction of phenolics and defense-related enzymes in coconut (Cocos nucifera L.) roots treated with biocontrol agents. Brazilian Journal of Plant Physiology, 18 (3).

Kim, S., Ahn, I.P., Park, C., Park, S.G., Park, S.Y. Jwa, N.S., and Lee, Y.H. (2001). Molecular characterization of the cDNA encoding an acidic isoform of PR-1 protein in rice. Molecules and Cells, 11: 115-121.

Linthorst, H.J.M. (1991). Pathogenesis-related proteins of plants. Critical Reviews in Plant Sciences, 10: 123-150.

Liu, Q. and Xue. Q. (2006): Computational identification of novel PR-1-type Genes in Oryza sativa. Journal of Genetics, 85 (3): 193-198.
Mayer, A.M., Harel, E. and Shaul, R.B. (1965). Assay of catechol oxidase a critical comparison of methods. Phytochemistry, 5 (4): 783-789.

Mayer, R.T., Inbar, M. and Doostdar, H. (1997). Are Pathogenesis-related proteins involved in plant resistance to insects? American society of plant biologist. oster: Plant Interactions with other organisms. 1120.

Mayer, R.T., McCollum, T.G., McDonald, R.E., Polston, J.E and Doostdar, H. (1996). Bemisia feeding induces pathogenesis-related proteins in tomato. In: Gerling, D. and Mayer, R.T., (eds.) Bemisia: taxonomy, biology, damage, control and management. Andover, Hants, UK: Intercept Ltd. Pp. 179188.

McKenzie, C.L., Shatters, R.G., Doostdar, Jr.H., Lee, S.D., Inbar, M. and Mayer, R.T. (2002). Effect of geminivirus infection and Bemisia infestation on accumulation of pathogenesisrelated proteins in tomato. Archives of Insect Biochemistry and Physiology, 49: 203-214.

Monreal, J. and Reese, E.T. (1969). The chitinase of Serratia marcescens. Canadian Journal of Microbiology, 15 (7): 689-696.

Puthoff, D.P., Holzer, F.M., Perring, T.M. and Walling, L.L. (2010). Tomato pathogenesisrelated protein genes are expressed in response to Trialeurodes vaporariorum and Bemisia tabaci Biotype B feeding. Journal of Chemical Ecology, 36 (11): 1271-1285.

Ramamoorthy, V. and Samiyappan, R. (2001). Induction of defense related genes in Pseudomonas fluorescens treated chilli plants in response to infection by Colletotrichum capsici. Journal of Mycology and Plant Pathology, 31: 146-155.

Ramamoorthy, V., Raguchander, T. and Samiyappan, R. (2002). Induction of defenserelated proteins in tomato roots treated with Pseudomonas fluorescens Pf1 and Fusarium oxysporum f. sp. Lycopersici. Plant and Soil, 239: 55-68.

Ren, Y.Y. and West, C.A. (1992). Elicitation of diterpene biosynthesis in rice (Oryza sativa L.) by Chitin, Plant Physiology, 99: 11691178.

Reymond, P., Weber, H., Damond, M. and Farmer, E.E. (2000) Differential gene expression in response to mechanical wounding and insect feeding in Arabidopsis. Plant Cell 12: $707-$ 719.

SAS (Statistical analysis system), (1997). SAS Institute. SAS/STAT User's Guide. Release 6.03 Edition-6th edition. SAS institute Inc., Cary, North Carolina,. U.S.A. 
Saikia, R., Singh, B.P., Kumar, R. and Arora, D.K. (2005). Detection of pathogenesis-related proteins-chitinase and $\beta$-1,3-glucanase in induced chickpea. Current Science, 89 (4): 659-663.

Saravanan, T., Bhaskaran, R. and Muthusamy, M. (2004). Pseudomonas fluorescens induced enzymological changes in banana roots $(\mathrm{Cv}$. Rasthali) against Fusarium wilt disease. Plant Pathology Journal, 3 (2): 72-80.

Shapiro, M., Preisler, H.K., and Robertson, J.L. (1987). Enhancement of baculovirus activity on gypsy moth (Lepidoptera: Lymantriidae) by chitinase. Journal of Economic Entomology, 80: 1113-1116.

Srinivasan, R. and Uthamasamy, S. (2004). Feeding induced changes in phenolics and pathogenesis-related proteins: implications in host resistance to Bemisia tabaci Genn. and Helicover armigera Hüb. In tomato accessions. Host Management in Horticultural Ecosystem,10 (2): 95-106.

Srivastava, R., Khalid, A., Singh, U.S. and Sharma, A.K. (2010). Evaluation of Arbuscular mycorrhizal fungus, fluorescent Pseudomonas and Trichoderma harzianum formulation against Fusarium oxysporum f. sp. lycopersici for the management of tomato wilt. Biological Control, 53 (1):24-31.

Stout, M.J. and Bostock, R.M. (1999). Specificity of induced responses to arthropods and pathogens. In: Agrawal, A.A, Tuzun, S. and Bent, E. (eds.) Induced plant defenses against pathogens and herbivores. St. Paul, MN: APS Press. pp. 183-209.

Stout, M.J. and Duffey, S.S. (1995). Characterization of induced resistance in tomato plants. Entomologia Experimentalis et Applicata, 79: 273-283.

Stout, M.J., Workman, J., and Duffey, S.S. (1994). Differential induction of tomato foliar proteins by arthropod herbivores. Journal of Chemical Ecology, 20: 2575-2594.
Stout, M.J., Workman, K.V. and Duffey, S.S. (1995). Identity, spatial distribution, and variability of induced chemical responses in tomato plants. Entomologia Experimentalis et Applicata, 79: 225-271.

Summers, C. B. and Felton, G. W. (1994). Prooxidant effects of phenolic acids on the generalist herbivore Helicoverpa zea (Lepidoptera: Noctuidae): potential mode of action for phenolic compounds in plant antiherbivore chemistry. Insect Biochemistry and Molecular Biology, 24: 943-953.

Taggar, G.K., Gill, R.S., Gupta, A.K. and Sandhu, J.S. (2012). Fluctuations in peroxidase and catalase activities of resistant and susceptible black gram (Vigna mungo(L.) Hepper) genotypes elicited by Bemisia tabaci (Gennadius) feeding. Plant singling and behavior, 7 (10): 1321-1329.

Van Loon, L.C. (1999). The families of pathogenesis-related proteins, their activities, and comparative analysis of PR-1 type proteins. Physiological and Molecular Plant Pathology, 55: 85-97.

Van Loon, L.C., Bakker, P.A.H.M. and Pieterse, C.M.J. (1998). Systemic resistance induced by rhizophere bacteria. Annual Review of Phytopathology, 36: 453-485.

Vance, C.P. Kirk, T.K. and Sherwood, R.T, (1980). Lignification as a mechanism of disease resistance. Annual Review of Phytopathology, 18: $259-288$.

Wang, X., Ding, X., Gopalakrishnan, B., Morgan, T.D., Johnson, L., White, F.F., Muthukrishnan, S. and Kramer, K.J. (1996). Insect Biochemistry and Molecular Biology, 26: 1055-1064.

Whipps, J.M. (2001). Microbial interactions and biocontrol in the rhizosphere. Journal of Experimental Botany, 52 (1): 487-511. 


\title{
الملخص العربى
}

\section{حث إنتاج البروتينات المرتبطة بالممرضات كآلية دفاع للنباتات ودورها في مكافحة ذبابة القطن Bemisia tabaci البيضناء}

\author{
أحمد محمد سليمان، ممدوح حسن إدريس، فاطمة أحمد المنياوي، إبراهيم عبده رواش

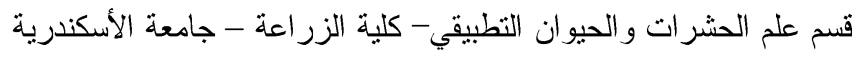

تمت در اسة تأثثر الإصابة بذبابة القطن البيضاء B. tabaci على نشاط بعض البروتينات المرتبطة بالممرضات polyphenol oxidase و و و هathogenesis-related (PR) proteins

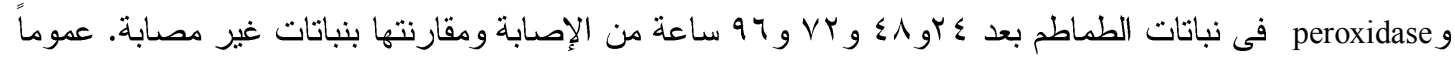

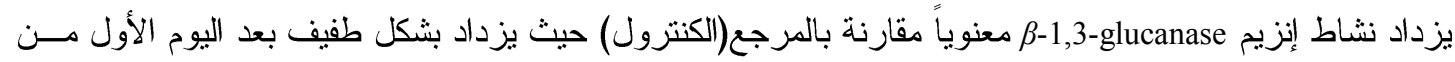

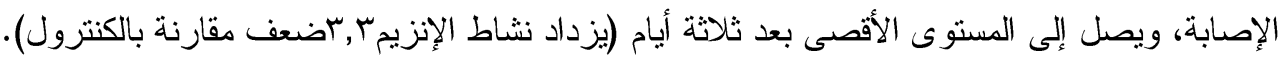

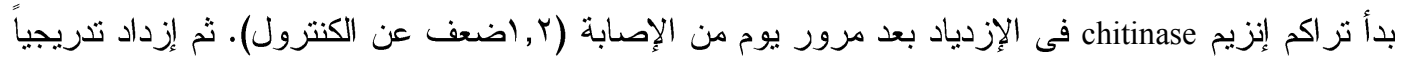

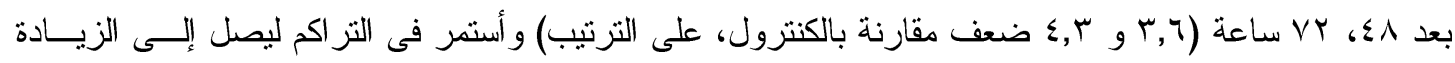

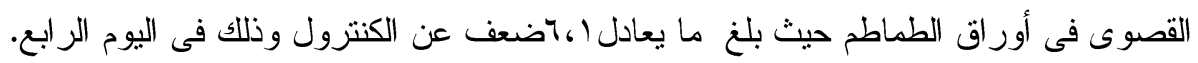

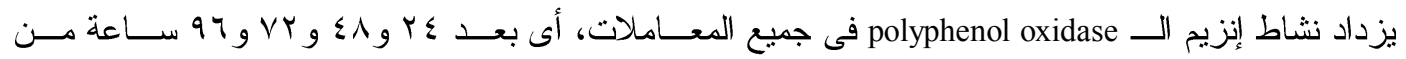

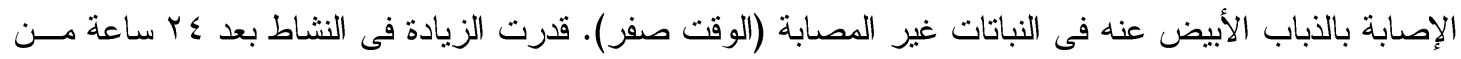

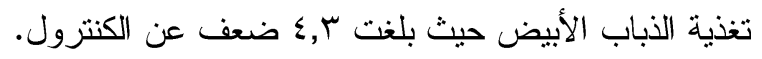

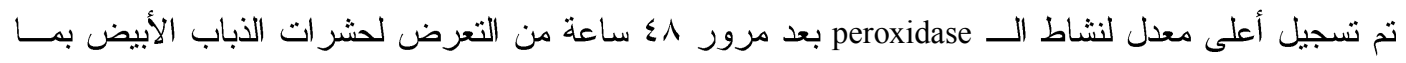

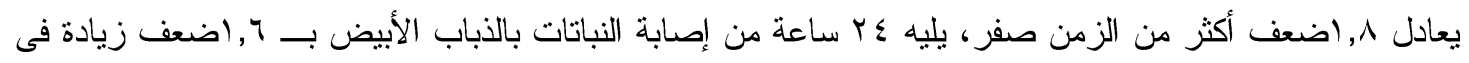

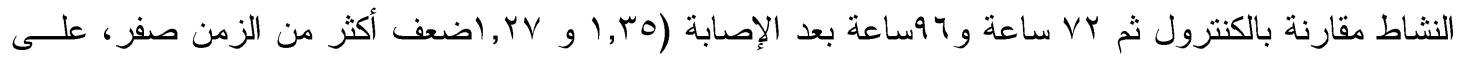
التزتيب).

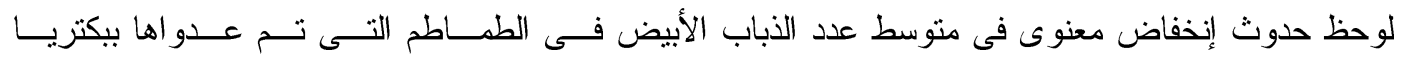
Pseudomonas chlororaphis

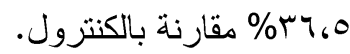

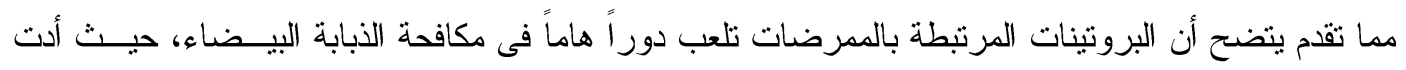

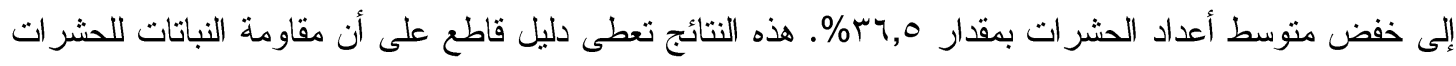

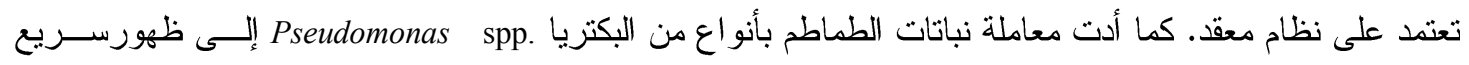
لنظام دفاعى ضد الآفات الحشرية. هذه النتائج قد تساعد فى تطوير خطة برنامج الإدارة المنكاملة للذبابــة البيــضاء فئاء تحت ظروف الزر اعات المحمية. 